\title{
Puras palabras. Sobre algunos de los usos de los testimonios en los documentales argentinos que evocan el pasado reciente
}

\author{
Gustavo Aprea*
}

Resumo: O artigo examina as diferentes formas de utilização e apresentação das palavras nos depoimentos em documentários argentinos que lembram o passado recente. Com esse objetivo analisa as origens dos documentários de memória na Argentina, descreve os modos dominantes e levanta as características gerais que definem os testemunhos do documentário. Finalmente propõe-se a analisar dois filmes contemporâneos que marcam ruturas com relação às formas usuais de trabalhar com os testemunhos: Palavras, de Ana Mohaded e Contas de alma: confissões de uma guerrilheira, de Mario Bomheker.

Palavras-chave: testemunho; documentário de memória; memória social; documentário contemporâneo.

Resumen: El artículo estudia diferentes formas de uso y presentación de las palabras en los testimonios en los documentales argentinos que recuerdan el pasado reciente. Con este objetivo repasa los orígenes de los documentales de memoria en Argentina, describe las modalidades dominantes y plantea las características generales que definen a los testimonios de los documentales. Finalmente se propone analizar dos films contemporáneos que establecen rupturas con respecto a las formas habituales de trabajar con los testimonios: Palabras, de Ana Mohaded y Cuentas del alma: confesiones de una guerrillera, de Mario Bomheker.

Palabras clave: testimonio; documental de memoria; memoria social; documental contemporáneo.

\begin{abstract}
The article studies different forms of use and presentation of words in testimonies in Argentine documentaries that recall the recent past. With this objective he reviews the origins of memory documentaries in Argentina, describes the dominant modalities and raises the general characteristics that define the testimonies of documentaries. Finally it proposes to analyse two contemporary films that establish ruptures with the habitual forms of working with testimonies: Words, by Ana Mohaded and Accounts of the soul: confessions of a guerrilla, by Mario Bomheker. Keywords: Testimony; documentary of memory; social memory; contemporary documentary.

* Universidad Nacional de las Artes. Departamento de Artes Audiovisuales. C1184ABC, Rocamora 4141, Buenos Aires. Argentina. E-mail: graprea@gmail.com

Sumisión del artículo: 1 de junio de 2017. Notificación de aceptación: 31 de julio de 2017.
\end{abstract}

Doc On-line, n. 22, setembro de 2017, www.doc.ubi.pt, pp. 143-162. 
Résumé: L'article examine les différentes formes d'utilisation et de présentation des mots dans les témoignages de documentaires argentins qui rappellent le passé récent. Avec cet objectif, il passe en revue les origines de la mémoire documentaire en Argentine, en décrit les modes dominants et soulève les caractéristiques générales qui définissent les témoignages des documentaires. Enfin, on propose d'analyser deux films contemporains qui établissent des ruptures par rapport aux moyens habituels de travail avec les témoignages : Mots, de Ana Mohaded et Comptes d'âme : confessions d'une guérilla, de Mario Bomheker.

Mots-clés : témoignage ; mémoire documentaire ; mémoire sociale ; documentaire contemporaine.

\section{Introducción}

La producción documental Argentina que reconstruye acontecimientos de la historia reciente del país es numerosa y variada. Su lugar resulta fundamental para la construcción de las memorias sociales y el debate permanente que la sociedad realiza sobre acontecimientos históricos que la mayor parte de las veces se viven como traumáticos. En diversas oportunidades ha sido señalada la apelación a las palabras de testigos como recurso central dentro del campo de los discursos audiovisuales que evocan el pasado. ${ }^{1}$ Este componente de la banda sonora de los documentales se convierte en uno de los ejes (en muchas oportunidades el principal) alrededor de los que se articulan las narraciones que interpretan eventos fundamentales para la construcción de identidades colectivas.

La importancia del registro de las palabras de los testigos puede relacionarse con distintos factores. En primer lugar, existe de una cuestión práctica común a la mayor parte de los films latinoamericanos que abordan temáticas conectadas con las luchas revolucionarias de las décadas de 1960 - 1970 y la feroz represión de las dictaduras que acabaron con ellas. Los testimonios brindan información sobre hechos alrededor de los que no hay otra posibilidad de acceso, ya sea porque se refieren a acciones realizadas en el marco de una actividad clandestina revolucionaria o porque tienen como objeto la denuncia de la represión estatal basada en una estrategia de ocultamiento. En el caso argentino es necesario señalar, además, que existe una gran deficiencia

1. En este sentido se pueden señalar entre otros los trabajos de Lorena Verzero (2009), Lorena Moriconi (2012), Pablo Piedras (2014), Gustavo Aprea (2015), Pablo Lanza (2016). 
Puras palabras. Sobre algunos de los usos de los testimonios en los documentales argentinos que evocan el pasado reciente

en la conservación del material de archivo fílmico por lo que el recurso a los testimonios tiende a adquirir un peso extra. ${ }^{2}$

Desde el punto de vista de la puesta en cámara y el montaje de los documentales el registro de las declaraciones de los testigos aparece como un elemento clave para el sostenimiento de la verosimilitud de los sucesos narrados. Todos los testimonios ponen en escena el acto de la evocación: hay al menos un testigo frente a la cámara y se dirige al espectador. Si los otros componentes de la puesta no lo contradicen, a partir de esta interpelación al público se construye el relato que permite organizar la explicación de los hechos históricos que se recuerdan. De esta manera, los documentales que trabajan con testimonios validan su lectura de la historia sobre una doble narrativa: la que cuenta cómo se recuerda desde el presente y la que se refiere a los acontecimientos del pasado. La existencia de los dos relatos (el de la evocación y el evocado) permite que la interpretación del documental se sostenga más allá de la falta de imágenes que actúen como documentos probatorios, las posibles contradicciones entre los declarantes y las subjetividades diferentes involucradas en las miradas sobre el pasado (Aprea, 2015).

La manera en que se hacen visibles las diferencias y tensiones entre los recuerdos personales y las diferentes versiones de las memorias colectivas le otorgan un interés especial al uso de los testimonios en los documentales de memoria. En Argentina desde la vuelta a la democracia en 1983 se mantienen la actualización y el debate sobre un pasado que deja huellas permanentes tanto entre los que lo vivieron como entre los que sufren sus consecuencias. Un análisis de los testimonios, sus modos de construcción y usos se presenta como una forma de abordaje pertinente para la comprensión de las diferentes formas en que la sociedad va procesando un pasado cada vez más distante pero siempre presente. Precisamente ésta es la reflexión que completa el resto del artículo.

\section{Algunos antecedentes de testimonios y documentales}

En la tradición documental Argentina la presencia de los testimonios no ha sido tan fuerte en los momentos previos al desarrollo de los documentales de memoria. Recién a mediados de la década de 1990 comienzan a perfilarse dos procesos paralelos que potencian el lugar de los testimonios audiovisuales y los documentales que buscan interpretar el pasado reciente argentino basándose en ellos. Por un lado, se abre una nueva etapa en la construcción de las memorias

2. Hay una descripción minuciosa de los problemas de los archivos audiovisuales en Argentina en el informe coordinado por Silvia Romano y Gonzalo Aguilar (2010) para la asociación Argentina de Estudios sobre Cine y Audiovisual. 
sociales en la que los que recuerdan el pasado dictatorial dejan de presentarse como víctimas y comienzan a presentarse como militantes políticos revolucionarios objeto de la persecución dictatorial. Con la llegada del kirchnerismo a la presidencia, esta postura fue la sostenida por el gobierno y se convirtió en la dominante, al menos dentro del terreno cinematográfico. (Feld, 2010; Aprea, 2011) Al mismo tiempo, el campo del documentalismo argentino comienza un proceso de especialización, primero y profesionalización después (Margulis, 2014). Por esta vía, la producción documental argentina comienza a crecer de manera exponencial. Los documentales de memoria sobre el pasado reciente constituyen una de las bases sobre las que se sustenta este proceso de institucionalización. A partir de dicho proceso se genera una cuantiosa producción dedicada al tema que rápidamente construye algunas convenciones que validan las formas de interpretación del pasado. Entre ella se encuentra la utilización de testimonios, no solo por el valor probatorio que éstos pueden llegar a tener sino por la capacidad de transmitir los aspectos subjetivos de las experiencias del pasado (mayormente traumáticas) que se evocan. De esta manera se consolida una tradición que prioriza el uso de los testimonios para organizar las narraciones que interpretan la historia reciente. Puede afirmarse que el sostén del hilo narrativo a través de testimonios que se combinan con imágenes de archivo tiende a reemplazar a la tradicional "voice of god" (de pretendida objetividad) que caracteriza a muchos documentales de montaje o simplemente expositivos. (Nichols, 2001).

\section{¿Cómo funcionan los testimonios en los documentales de memoria?}

El proceso de institucionalización del campo documental facilita la conformación de estándares que de alguna manera regularizan y le otorgan una especificidad a los testimonios. Se puede pensar al testimonio como un dispositivo de tipo dialógico (un intercambio entre dos o más personas) que se utiliza en diversas esferas de la vida social (la justicia, las ciencias sociales, el periodismo) y se presenta en múltiples soportes (oral, escrito, audiovisual). En todas estas variantes se repiten tres figuras que pueden estar presentes de manera explícita o implícita: un testigo cuyas palabras son valoradas en función de una experiencia vivida y recordada; un solicitante que realiza la primera escucha de las palabras del testigo; un destinatario que puede asociarse a un público concreto como los presentes en una sala judicial o presentarse como un concepto como la Historia. Además de estas características comunes a toda actividad testimonial, las palabras de los testigos en los documentales tienen rasgos distintivos. Quedan registradas y pueden ser manipuladas. Aunque suelen configurarse como relatos, se incluyen necesariamente dentro de una 
Puras palabras. Sobre algunos de los usos de los testimonios en los documentales argentinos que evocan el pasado reciente

narración mayor, la que organiza el documental. Involucran no solo lo que se dice, sino cómo se dice, de tal modo que pueden resultar tan significativos como lo dicho, los elementos gestuales y paralingüísticos. (Aprea, 2015) Además de por estos elementos, la credibilidad de las palabras de los testimonios queda condicionada por lo que en términos de Pessoa Ramos (2012) conforma la mis en scene de todo documental. En principio encuadres y la iluminación, lugares y movimientos escogidos, los carteles de presentación, la sonorización y otros recursos audiovisuales permiten validar la credibilidad de los testigos y la empatía con respecto a sus declaraciones. Por sobre esto, las palabras de los testigos se enmarcan en series (visuales, sonoras, otros testimonios) que termina por sostener o destruir su credibilidad.

En el marco de los documentales de memoria argentinos que evocan el pasado reciente el trabajo con los testimonios apela mayoritariamente a la pluralidad de voces individuales que reconstruyen los acontecimientos evocados. A través de ellas se sigue el hilo de la narración y se articula una interpretación de la historia. Los otros componentes del documental como el material de archivo, los carteles y la musicalización se presentan como materiales complementarios que potencian la centralidad de la palabra de los testigos y ocupan un tiempo generalmente escaso dentro de los filmes.

Los estudios que plantean una mirada abarcadora sobre la producción de documentales de memoria en Argentina describen algunas estrategias comunes para el uso de los testimonios en los documentales que re-construyen el pasado reciente (Russo, 2009; Piedras, 2014; Aprea, 2015; Lanza, 2016).

En algunos casos como Cazadores de utopías (Blaustein, 1995) la sumatoria de testigos construye una voz colectiva que trae al presente una lectura (en este caso la de la generación militante) del pasado. En ella el material de archivo noticioso ilustra las declaraciones que organizan un relato lineal. Un autor como Nicolás Prividera en $M$ (2007) contrasta las declaraciones de los compañeros y amigos de sus padres para investigar la desaparición de su madre y las relaciona con imágenes del archivo íntimo de la familia. Aun en un caso como Los rubios de Albertina Carri (2003) que critica los componentes básicos habituales de los documentales de memoria (testimonios y materiales de archivo), la linealidad narrativa y las conclusiones cerradas, las palabras de los testigos tienen una presencia importante. Se desconfía de ellos pero aparecen como parte de una mis en scene en la que se prioriza el acto de evocación por sobre la reconstrucción del pasado.

Sobre estas apreciaciones se suelen delimitar en los trabajos académicos dos grandes tipos de lectura y narración del pasado reciente (Aguilar, 2006; Piedras, 2014; Aprea, 2015). Por un lado, los documentales que a través de la 
acumulación de múltiples testimonios construyen una mirada que se presenta como colectiva y desarrollan un relato que, en clave heroica, evoca un pasado compartido que de alguna manera puede ser transmitido al conjunto de la sociedad. Este tipo de uso de los testimonios no excluye ni el material de archivo ni las dramatizaciones, de ser necesarias. Se suele señalar el comienzo de esta modalidad en el film Andrés Di Tella Montoneros, una historia (1994), pero se prolonga hasta nuestros días en biografías de revolucionarios como Carlos Olmedo en Última carta sobre la revolución (Pablo Spatola, 2016). Abarca tanto recorridos de trayectorias militantes como la del ERP en Gaviotas blindadas (Mascaró Cine Americano, 2006- 2008) reconstrucciones de sucesos como la masacre narrada en Trelew (Mariana Arruti, 2003).

Por contraposición a esta propuesta mayoritaria, aparecen las narrativas en primera persona, identificadas con la clasificación de documental performativo (Nichols, 2001) que se caracterizan por la presencia activa de los realizadores en la reconstrucción de su pasado cercano del que toman distancia. La imposibilidad de transmitir la experiencia traumática de una revolución fracasada involucra tanto a los miembros de la generación militante como a los pocos realizadores que terminan negando tanto la posibilidad de un destino épico como de la construcción de una memoria que posibilite la acción política colectiva. Suele asociarse esta posición que enfatiza la subjetividad individual de la mirada sobre el pasado construida con la generación de los hijos de los militantes desaparecidos, tal como sucede en las ya citadas Los rubios y $M$.

\section{Dos casos en los límites que adoptan una actitud reflexiva sobre el testi- monio}

Dentro de este contexto en que se estabilizan diferentes modalidades de uso de los testimonios en los documentales que evocan el pasado traumático puede destacarse un par de films que con estrategias diferentes (casi contrapuestas) fuerzan los límites de los usos habituales de la presencia y la palabra de los testigos: Palabras de Ana Mohaded (2009) ${ }^{3}$ y Cuentas del alma. Confesiones de una guerrillera de Mario Bomheker (2012). ${ }^{4}$

3. Palabras es un cortometraje de 21 minutos. Se presentó en el Teatro Libertador San Martín de Córdoba el 10 de diciembre de 2008. Luego circuló por festivales, instituciones académicas y organizaciones sociales tanto en Argentina como en el extranjero. Nace por la invitación del Equipo Acompañamiento a testigos y querellantes en el marco de los juicios contra el terrorismo de Estado. Fue apoyado por la Universidad Nacional de Córdoba y la productora Kipus Documenta, ligada a la Central de Trabajadores Argentinos. La producción y la dirección son de Ana Mohaded.

4. Cuentas del alma. Confesiones de una guerrillera es un largometraje de 72 minutos. Hizo su primera exhibición pública en el BAFICI de Buenos Aires en 2012 y se estrenó en salas en de Córdoba el 9 de agosto de 2012. Luego se exhibió en salas comerciales de Buenos Aires. 
Puras palabras. Sobre algunos de los usos de los testimonios en los documentales argentinos que evocan el pasado reciente

Más allá de las diferencias de enfoque, estilísticas y temáticas tienen una serie de rasgos en común. Uno de ellos es su origen: la provincia de Córdoba. En un país en que, entre muchas otras cosas, la producción audiovisual se encuentra mayoritariamente concentrada en la ciudad de Buenos Aires, las películas realizadas fuera de ella se encuentran en un lugar marginal y tienen muchas más dificultades para circular en todo el territorio nacional. De un modo paradojal, en la construcción de las memorias sociales sobre el pasado reciente Córdoba ocupa un lugar central. En dicha provincia los movimientos revolucionarios setentistas alcanzaron la mayor difusión, radicalidad y variedad. Consecuentemente el accionar represivo en dicha zona fue de una ferocidad particular y sus consecuencias marcan con fuerza hasta la actualidad a la sociedad cordobesa.

Una segunda cuestión que une a los dos films es que sus directores pertenecen a la generación militante de los setenta y sufrieron en distinta medida la represión dictatorial. Mario Boemheker se exilió durante la dictadura y Ana Mohaded estuvo "desaparecida” y luego presa política entre 1976 y 1982. Es decir que ambos reflexionan de diferentes maneras sobre experiencias que afectaron directamente sus vidas siendo adultos.

Más allá de estas coincidencias, tanto Palabras como Cuentas del alma tienen un rasgo en común que las acerca entre sí y al mismo tiempo las diferencia del grueso de los documentales de memoria argentinos: configuran un relato que busca evocar e interpretar acontecimientos del pasado a través de un único testimonio. No pretenden armar narrativas corales, ni contraponer puntos de vista sino desarrollar su lectura del pasado a partir de las palabras y la gestualidad de un solo personaje. Desde esta perspectiva, la elección de la modalidad de mis en scene de los testimonios aparece como un elemento clave comprender la lógica que ordena los relatos que interpretan el pasado evocado.

\section{Cuentas del alma: la escucha de las palabras desautorizadas}

En 2012 se estrena Cuentas del alma. Confesiones de una guerrillera un documental de Mario Bomheker que se basa en un extenso testimonio de Miriam P., una ex militante del PRT-ERP. ${ }^{5}$ Este trabajo plantea una serie de rasgos que lo distancian del tipo de uso habitual de los recuerdos que evocan el pasado

Contó con financiamiento del INCAA y fue Distribuida por Cine Ojo. Sus guionistas son Mario Bomheker, Susana Romano Sude y Carmen Guarini.

5. El Partido Revolucionario de los Trabajadores - Ejército del Pueblo fue una de las mayores organizaciones revolucionarias que optaron por la lucha armada en Argentina durante los Setenta. Tenía especial arraigo en el interior del país y entre 1974 y 1976 emprendió un foco de guerrilla rural en la provincia de Tucumán. Allí fue a militar, resultó herida y cayó presa Miram P..Una vez en poder de los militares aceptó declarar el arrepentimiento por sus acciones revolucionarias frente a la prensa. Sus declaraciones fueron presentadas en su ciudad natal, 
dictatorial. Introduce novedades tanto en la estética del documental como en el modo de encarar una problemática que resulta muy cuestionada en este tipo de reconstrucciones del pasado: la traición a la causa revolucionaria.

La mayor parte del film está ocupada por el testimonio de la protagonista que fue registrado en una única jornada y un solo lugar: su casa en Israel. Trabajar con un solo testigo es poco habitual dentro de los documentales de memoria argentinos, aunque dentro del documentalismo internacional existen algunas obras que se organizan en torno a entrevistas a personajes. ${ }^{6}$ En estos casos, si bien las palabras de los entrevistados constituyen el eje vertebrador de dichos textos, suelen contener además otro tipo material que ilustra sus dichos (materiales de archivo público o íntimo, musicalización) que funcionan como validación y refuerzo de lo expresado por los personajes que brindan su testimonio. ${ }^{7}$ En Cuentas del alma, no sucede esto. El documental no homenajea ni juzga abiertamente a su protagonista. La entrevista que realiza el director ocupa el centro del relato sin la inserción de ningún elemento externo ni en las imágenes ni en la banda sonora.

El film se abre con dos textos sobre un fondo oscuro que explican: qué fue el Ejército Revolucionario del Pueblo y cuál fue su trágico destino seguido por otro que da sentido a la expresión hebrea Jeshbon Nefesh (cuentas del alma) como un momento en que los miembros de la comunidad judía deben recordar y asumir la responsabilidad por los actos desarrollados durante el año que acaba de pasar. Sigue una brevísima presentación de los antecedentes del personaje narrados por la voz del director sobre la imagen de una nota de un diario de 1976. La acción se ubica en la Biblioteca Nacional de Buenos Aires. La introducción culmina con una secuencia que une varios traveling largos mediante los que la cámara narra el recorrido hacia la casa de Miram P. en el pueblo israelí Gav Yavne.

El testimonio arranca con un plano americano en el que aparecen juntos el director y la protagonista sentados en un sillón dentro de la casa. A partir del momento en que la voz de Bomheker termina de plantear su interés por la historia que se va a narrar, Miram P. aparece sola en la pantalla siempre

Córdoba, el mismo día del golpe militar del 24 de marzo de 1976. Por eso su figura es recordada y aparece como un epítome de la traición.

6. En el plano internacional existen antecedentes en este tipo de planteo. Por ejemplo: Otelo Saraiva Carbalho, uno de los dirigentes del golpe contra el régimen salazarista de Portugal, narra en La noche del golpe de estado. Lisboa, 1974 (Ginette Lavigne, 2001) sus experiencias desde el mismo bunker en que comandó el centro de comunicaciones de los rebeldes o Traudl Junge, en La secretaria de Hitler (André Heller y Othmar Schmiderer, 2001) narra los últimos tiempos del dictador y su círculo íntimo.

7. Dentro de los documentales que recuperan trayectorias militantes basados en homenaje a quienes presentan testimonios pueden citarse Juan Germán y otras cuestiones (Jorge Dente, 2005), La escuela (Eduardo Yedra, 2006) sobre Miriam Lewis y Horas de vida (Lucy Reyes, 2006) sobre Susana Reyes. 
Puras palabras. Sobre algunos de los usos de los testimonios en los documentales argentinos que evocan el pasado reciente

encuadrada en planos medios o primeros planos que rescatan su gestualidad relajada. El monólogo ${ }^{8}$ testimonial se extiende por los siguientes 65 minutos. Solo después de los títulos finales reaparece el director junto con Miriam P. frente a una mesa con fotos que hacen referencia a la vida que se acaba de contar. Reafirmando lo que sostiene en su testimonio la protagonista lee sus "confesiones" de 1976 y acuerda con el texto de la nota periodística que inició el documental.

De esta manera Miriam P. se constituye en la articuladora de la narración de su vida transformando sus palabras en el hilo del relato que constituye el foco de atención. A diferencia de otras estrategias que buscan resaltar la figura de los testigos despegándolos del fondo, la protagonista cuenta su historia en su ambiente cotidiano. El rodaje transcurre en su casa incluyendo dentro de la escena testimonial, situaciones no previstas como la vuelta del marido a la casa durante la entrevista. El ambiente en el que se desarrolla el testimonio es hogareño y luminoso. La iluminación tiene pocos contrastes, la figura de Miriam aparece recortada y nítida. El énfasis del encuadre se pone en el rescate de gestos y actitudes cotidianas. Como fondo aparece una ventana que da un jardín con plantas. Se genera así una distancia entre el ambiente de la evocación y el sentido trágico de los acontecimientos evocados. A esta característica se suma el tono exento de dramatismo con que la testigo narra los episodios trágicos de su experiencia. El distanciamiento con los sucesos que evoca incluso puede llegar a la ironía. Su biografía incluye múltiples elementos dramáticos que exceden su declaración de arrepentimiento público en una conferencia de prensa. Todos estos hechos son presentados sin intervenciones airadas o violentas. Cierta sonrisa nerviosa que se repite, los silencios y el modo presentarse ante la cámara son los componentes que expresan la subjetividad de la narradora. Podría decirse que actúan como lapsus que permiten intuir el desgarramiento interno que sufre o sufrió Miriam P. a través de una experiencia sin dudas traumática. ${ }^{9}$

Durante el desarrollo del testimonio Bomheker solo participa con algunas intervenciones en off, acotando detalles o aclarando asuntos con la protagonista en hebreo. Su trabajo se orienta hacia que la testigo se sienta lo más cómoda posible para desarrollar su historia y explicar sus posiciones. Si bien

8. Puede afirmarse que se construye un monólogo ya que se trata de una escena en la que un personaje se dirige a la cámara y narra su historia. La mediación del director a través de preguntas que quedan fuera del montaje queda minimizada y sus acotaciones no hacen otra cosa dar fuerza a la palabra de la monologuista. (Pavis, 1998: 297-299)

9. Tal como relata en su testimonio, Miriam P. quedó huérfana siendo muy joven, perdió la relación con su pareja al caer prisionera, sufrió vejaciones por parte de los militares, el desprecio de sus ex compañeros, vivió un exilio en Paraguay con nombre falso, hasta que finalmente logró establecerse en Israel e iniciar una nueva vida. 
los recortes de fragmentos en la edición final no son ocultados (hay fundidos a negro, saltos de raccord), el relato de una vida plena en episodios impactantes tiene una continuidad lineal evidente y resulta fluido ${ }^{10}$. La escena general que se construye es la de una confesión en la que la testigo expresa abiertamente todo lo que piensa y siente que tiene que decir.

Por su parte, la testigo asume su rol a través de una actitud calmada. Relata las diversas circunstancias conflictivas que tuvo que padecer de un modo que se aleja del dramatismo. Su narración se distancia permanentemente de los hechos evocados. Mantiene un tono sosegado que no expresa indignación ni enfatiza el sufrimiento. Plantea un balance de su trayectoria desde una perspectiva que apela a la racionalidad en la que se entrelazan sucesos excepcionales y asuntos cotidianos. Más allá del acto de abandono de una postura política y el pacto con sus enemigos, la confesión de 1976 implica también una ruptura violenta con el grupo que había suplantado a su familia e incluía a su propia pareja y en torno al cual había construido su identidad hasta el momento.

La relación que se establece en el transcurso del encuentro entre Miriam P. y Mario Bomheker permite, por un lado, que la testigo exprese lo que quiere o puede decir y, por otro, que se logre escuchar lo que hasta el momento aparecía como inaudible. Si bien el centro de la narración son las palabras de Miriam P., la presencia en off del realizador hace que el contacto entre la testigo y el entrevistador le confiera un aspecto confesional a las declaraciones. La testigo no le habla a la cámara sino a otra persona. El tipo de escucha construida se distingue de las formas del documental expositivo clásico en el que los dichos de los testigos parecen dirigirse directamente al espectador o la posteridad. Pero también se diferencia del tipo de utilización de los testimonios característicos de los documentales en primera persona. En ellos, los realizadores disputan el protagonismo con testigos y en muchos casos no dudan en generar situaciones tensas y conflictivas que pueden llegar a desvalorizar las declaraciones de los entrevistados. La escena construida en Cuentas del alma establece un juego de distancias que permite escuchar una lectura del pasado que quiebra lo aceptado hasta el momento en relación con la militancia revolucionaria. Por un lado, genera una sensación de proximidad a través del modo en que se construye y exhibe la relación entre el realizador y la testigo. Por otro, en la introducción donde el realizador presenta el caso se apela a una exposición distanciada de los acontecimientos que choca con el acercamiento que se produce en la escena final en la que Mario y Miriam revisan fotos del pasado. Las distancias entre el entrevistador y la testigo visibles en las mira-

10. Evidentemente las declaraciones no siguieron un orden cronológico lineal, pero la edición organizó la trama de los acontecimientos siguiendo la linealidad de la historia. 
Puras palabras. Sobre algunos de los usos de los testimonios en los documentales argentinos que evocan el pasado reciente

das que el realizador realiza a la protagonista durante la secuencia final. Pese a ello, se ha avanzado en la comprensión de una lectura del pasado que hasta el momento estaba reducida al espacio de lo aberrante: la de los "quebrados", los traidores. Las palabras de la testigo en Cuentas del alma no se usan para justificar o atacar esta posición polémica, sino que se las presenta como una vía para la interpretación de una postura difícil de escuchar: la aceptación de la traición y la falta de arrepentimiento por dicha acción.

La elección del personaje que testimonia implica un cambio significativo con respecto a las opciones habituales. Miriam P. no fue una militante de peso dentro de su organización, ni una víctima que narra los sufrimientos de los procesos de desaparición. Es famosa porque se la considera una traidora. Ni bien producido el golpe militar da una conferencia de prensa que aparece por televisión, diarios y revistas de la época ${ }^{11}$ como parte de la campaña a través de la cual los medios de comunicación buscan congraciarse con el nuevo gobierno. En el transcurso de sus declaraciones Miriam P. expresa su convicción de que se debe transformar el mundo sin el uso de la violencia y critica a la conducción política del ERP que la abandonó a su suerte. Al ser considerada una traidora, se dificulta la audibilidad ${ }^{12}$ de sus palabras como sobreviviente de la represión dictatorial de sus palabras. No encuadra ni en el modelo de la víctima inocente que se estableció durante los primeros años de la recuperación democrática, ni en el de militantes heroicos que con sus diversas variantes se difunde desde mediados de la década de 1990. Las conclusiones sobre el origen sus convicciones revolucionarias y su críticas a la actuación del ERP resultan casi opuestas a las de los sobrevivientes de los campos de concentración. ${ }^{13}$ Por todas estas cuestiones, aunque la experiencia de de Miriam P. fue también traumática, su testimonio aparece como la figura de aquél que pactó con el Mal. Esto plantea serias dificultades para acercarse al personaje que ha ido construyendo a través de toda su vida de sobreviviente.

En este sentido el testimonio de Miriam P. introduce varias novedades dentro las reconstrucciones audiovisuales del pasado traumático. En primer lugar, pese a la gravedad de los acontecimientos recordados quiebra la lectura trágica sobre la historia reciente que parece caracterizar a las realizaciones contemporáneas. Luego, aborda el problema de la identidad de una manera que complejiza ciertas posiciones esquemáticas. Miriam P. debe reconstruir la suya a

11. El título con que el diario La voz del interior (Miriam P. y Mario Bomheker son cordobeses) fue "Confesiones de una guerrillera", segunda parte del nombre del documental.

12. Se utiliza el término audibilidad en el sentido que le da Ana Longoni (2007) como la dificultad - que puede llegar a la imposibilidad - que tiene la sociedad para absorber las palabras de los sobrevivientes de los procesos de desaparición que va variando a través de los años.

13. También difiere de aquellos que, una vez caídos prisioneros, se convirtieron en colaboradores activos de la represión y, en general, carecen de palabra pública. 
través de pertenencias que sostienen diversas memorias colectivas: como judía que pasa de un grupo sionista a una guerrilla marxista cuya derrota la convierte en una paria que termina viviendo en Israel; como argentina que debe vivir diferentes exilios; como sobreviviente debe construir una versión que no comparte la mirada canónica sobre el pasado de la lucha armada. Finalmente, el documental construye una mirada política que analiza el pasado y el modo en que se lo reconstruye. No aparece lo que "se debe decir" sobre una historia varias veces contada. Se hace un esfuerzo por escuchar una lectura difícil de aceptar al mismo tiempo que a través del modo en que se organiza y escenifica la recordación se reflexiona en torno a las tensiones que existen entre los recuerdos personales y las memorias colectivas. De esta manera, Cuentas del alma no solo escenifica un acto de evocación del pasado, sino que además construye una escena en la que se construye el ambiente para escuchar una voz que resulta disonante dentro del conjunto de las memorias sociales.

\section{Palabras: nos queda la palabra}

El corto de Ana Mohaded se encuadra dentro de los documentales de ensayo que adoptan una forma libre $y$, a la vez, recupera elementos de un género de tradición campo del videoarte: el autorretrato. A partir de estas bases complejas Palabras se presenta como un soliloquio ${ }^{14}$ en el que la protagonista / directora evoca su pasado como víctima de la represión y reflexiona sobre su rol frente a su próxima participación como testigo en un juicio por crímenes de lesa humanidad realizado en la ciudad de Córdoba. El grueso del documental se organiza alrededor de un plano medio de Ana Mohaded mirando a cámara que se edita por sobreimpresión o corte con distintos tipos de imágenes: la propia Ana encuadrada desde un punto de vista diferente que pone el foco en detalles como sus manos en el teclado de la computadora o sus gestos de perfil; algunas tomas de archivo sobre la represión dictatorial y homenajes a desaparecidos; esquemas dibujados a mano sobre los centros clandestinos de detención; textos escritos que aparecen en la computadora o se proyectan sobre un fondo; imágenes abstractas productos de juegos de luces y colores.

La voz que sostiene las evocaciones y reflexiones de la testigo aparece sola, aislada de todo sonido externo que no sea el de las teclas de una computadora. Sus palabras se presentan en un amiente deliberadamente artificial que se fortalece con otros elementos de la puesta en escena: la contraposición entre la blusa blanca del personaje y el fondo negro sobre el que aparece, la iluminación contrastada que intensifica el dramatismo frente a un rostro que

14. Palabras puede ser asociado a la forma dramática soliloquio ya que se trata de reflexiones en voz alta de un personaje que expresa sus pensamientos íntimos. (Pavis, 1998: 430) 
Puras palabras. Sobre algunos de los usos de los testimonios en los documentales argentinos que evocan el pasado reciente

no tiene una gesticulación exagerada. Parece que la sombra de un barrote le cruza el rostro pero habla como en una charla cotidiana. La entonación de las declaraciones y recuerdos de Ana Mohaded quiebran deliberadamente la sensación de estar viendo un testimonio espontáneo. Por momentos se acentúa el hecho de que las palabras expresadas son producto de la escritura. No se trata de una improvisación. Cuenta su vida pero pensó lo que está diciendo. Sin embargo, esta actitud que rompe con una pretendida naturalidad se distancia de la utilización de un vocabulario que apela a lo familiar e íntimo con el uso de diminutivos, apodos o expresiones coloquiales ${ }^{15}$. Tiene un acento localista que no oculta. La gestualidad medida y el tono confesional con que habla la protagonista generan un efecto de sinceridad. Ana no finge. Su modo de hablar expresa su biografía. Es una profesora universitaria que mezcla citas a escritores o políticos, una militante que dice las cosas por su nombre y una provinciana que puede apelar a las formas de habla populares. La exposición de su persona genera un acercamiento a las palabras que se opone al marco teatral en que están dichas. Dentro de este clima de intimidad el espectador es interpelado. En un plano medio Ana lo mira casi frontalmente a través de la cámara. Varias veces se dirige a él y dice: "sabés", "ves".

Toda esta expresión de los pensamientos íntimos en un marco de distanciamiento choca con la estética de la coda final del film. Cuando Ana Mohaded termina de hablar irrumpe en la pantalla una voz masculina (el Secretario del Juzgado) que lee el veredicto final del juicio al que debía presentarse en la que se condena a los culpables en medio de ovaciones aplausos. El cierre culmina en la canción de Paco Ibáñez "Nos queda la palabra" ${ }^{16}$, basada en un poema de Blas de Otero titulado "En el principio". En este final apoteótico acompañan a la banda de sonido imágenes de movilizaciones por los Derechos Humanos que festejan los fallos judiciales y recuerdan a los desaparecidos. Entre el fin del testimonio de la directora / testigo y la última secuencia no solo se produce una elipsis temporal evidente (del momento previo al testimonio en el juzgado a la resolución del juicio), sino que se pasa de un universo íntimo y reflexivo a otro que manifiesta una explosión colectiva.

Siguiendo la estética de los autorretratos audiovisuales la presentación de los hechos evocados es fragmentaria y no sigue una linealidad de orden cronológico ${ }^{17}$. Las ideas de Ana Mohaded pasan del pasado (recuerdos de la mili-

15. Expresiones como «la gran flauta» o «bañadita y cambiadita como dicen en mi pueblo».

16. Las canciones musicalizadas y cantadas por el cantante español exiliado Paco Ibáñez sobre versos de poetas sociales fueron sumamente populares entre los militantes políticos de la década de los Setenta.

17. Tal como plantea Raquel Schefer refiriéndose al video arte "El autorretrato como retrato/imagen ('dibujo') del sí mismo como otro trastocan el concepto de 'mimesis' y rompen parodísticamente con las normas y convenciones literarias y artísticas establecidas." (Schefer, 
tancia y la tortura) al presente (preparativos para la declaración en el juzgado) y se proyectan hacia un futuro incierto (¿cómo funcionará la declaración?, ¿los represores serán declarados culpables?). Pese a que estos pensamientos son presentados en forma discontinua terminan construyendo una reflexión sobre el acto de recordar y las formas de transmitir una experiencia. En este caso lo que se evoca y cuenta varias veces tiene una dimensión traumática que la protagonista no expresa abiertamente pero se desprende por la yuxtaposición de recuerdos traumáticos y su contraste con las circunstancias de su vida privada como el entierro de su madre. Sería bueno olvidar pero no se puede. Por eso las primeras palabras del testimonio hablan de una recuperación de la capacidad sanadora del olvido.

A través de esta opción estética Palabras construye un relato en primera persona que, como en todos los testimonios, hace visible el proceso de recordación. Solo que en este caso las figuras de testigo, protagonista de un soliloquio y realizadora coinciden en una sola persona. En este punto debe considerarse una relación entre Palabras y los documentales performativos que se produjeron sobre una temática similar. La presencia activa del realizador en la acción narrada y las referencias autobiográficas resultan evidentes. Más allá de estos rasgos comunes, en el corto de Mohaded se constituye un tipo de reflexividad particular. Su estrategia de puesta en escena permite que se testimonie el testimonio. Es decir que se da cuenta del acto de recordar como un dispositivo construido y visibilizado para transmitir una vivencia personal que termina relacionándose con una experiencia colectiva. El soliloquio comienza con dos preguntas: en la pantalla se lee "¿PARA QUIÉN ES EL JUICIO?"y Ana Mohaded se pregunta "El olvido sirve para protegerse. ¿Y la memoria paraqué sirve?". A partir de esta doble interrogación el documental desarrollo su reflexión sobre la acción de testimoniar. No solo registra y preserva las declaraciones del testigo sino que a través de la mis en scene las expresa y analiza en un mismo movimiento (Renov, 1993) el acto de recordación. En este sentido puede hablarse de un caso de enunciación audiovisual enunciada tal como describen Christian Metz (1991) e Ismail Xavier (2008).

La actitud reflexiva que plantea la forma de presentación del testimonio permite que la mirada del documental se extienda sobre cuestiones que por lo general no son consideradas. Testimoniar tiene costos y genera consecuencias. La repetición de los recuerdos ${ }^{18}$ traumáticos (tortura, violencia, compañeros

2011: 212). En este género se pueden combinar libremente fuentes diversas unidas por la imagen o la voz del realizador/retratista que puede presentar historias del plano íntimo de un modo fragmentado que no implica necesariamente una narración lineal.

18. Ana Mohaded como muchos de los desaparecidos tuvo que relatar en múltiples ocasiones sus experiencias traumáticas: ante diversas comisiones ligadas a la defensa de los Derechos Humanos, ante la Comisión Nacional sobre la Desaparición de Personas, en los juicios aborta- 
Puras palabras. Sobre algunos de los usos de los testimonios en los documentales argentinos que evocan el pasado reciente

asesinados) causa un dolor que no se quiere o no se puede manifestar abiertamente. Además hace que las imágenes del pasado se vayan modificando e integrando con otras banales ("Me sentí una boluda. Yo con mi blusa para ir al juicio y los compañeros que no están") o chocar con otras siniestras ("Se acordará Menéndez [el jefe de la banda asesina] de la belleza de Elena embarazada"). Pero además recordar tiene consecuencias que exceden la simple la transmisión de una experiencia personal. Se enmarca en la recuperación de una perspectiva ideológica "igualitaria, ética y libertaria"y culmina con la condena a los responsables los campos de exterminio que se presenta al final del documental. De esta manera, el film construye un mundo en el que las palabras tienen valor y se convierten en acciones que traen el pasado al presente, transmiten los recuerdos en declaraciones públicas y logran una condena jurídica. Por esta vía se articulan la "subjetividad" de los trabajos de memoria con la capacidad probatoria que sostiene la "objetividad" de los dictámenes judiciales.

Más allá de estas cuestiones, las palabras se presentan a través de una sola voz, (otra de las originalidades del film): la de la testigo. A diferencia de los procedimientos estandarizados el testimonio de Ana Mohaded aparece como el espacio combina procesos complejos. Es mucho más que una testigo que evoca hechos históricos. Se la conoce como hija, madre, militante, ex desaparecida, compañera de los que no pueden declarar y amiga de los que la acompañan. Al mismo tiempo, su discurso condensa una polifonía en la que aparecen múltiples voces: las de los que no están, las de los que la acompañan o las de los propios torturadores. Puede asumir directamente las palabras de una policía torturadora " $¡ U y$ ! ¡Se me hace tarde! Me voy que tengo que darle la teta al bebe"o citar literalmente a un prócer nacional "San Martín dice que no es soplar y hacer botellas". Pero también su figura puede aparecer a través de las palabras de otros expresadas indirectamente por ella: "cuando el Ñato y el Claudio me dijeron que estaba propuesta como testigo en el juicio a Menéndez y su patota, me dieron ganas de llorar". Tal como la propia Ana afirma, en su memoria "hay mucha gente". Todos condicionan sus recuerdos. Pero también, cuando testimonia no habla solo de su experiencia personal, asume la palabra por los que no pueden tenerla, por otros que la tienen y no la usan y también reconoce que sus recuerdos están cruzados por las voces y las acciones de aquellos que la torturaron. De esta manera, al mismo tiempo que narra vivencias personales, puede reconstruir una experiencia colectiva. Por esta vía la acción de testimoniar y las palabras tienen un efecto curativo. Se

dos de la década de 1980 y en los que se generaron a partir de la derogación de los indultos a los genocidas en 2006. 
pueden narrar sucesos traumáticos que generan una gran incertidumbre ante el futuro (no existen garantías plenas de que no se repitan), pero el hecho mismo de transmitirlos permite conjurar los miedos que un pasado opresivo genera.

\section{Conclusiones}

Tanto Palabras como Cuentas del alma: confesiones de una guerrillera son dos documentales que se recortan de las tendencias dominantes en la producción documental sobre la memoria en Argentina. Si bien se las puede considerar como el resultado de una tradición que trabaja con testimonios para reconstruir el pasado traumático, establecen quiebres con respecto a las modalidades de presentación de dicho pasado. Tal como planteamos anteriormente se pueden distinguir dos grandes maneras de utilizar los testimonios para interpretar acontecimientos de la historia reciente. Por un lado se encuentran los films que acumulan testimonios que pueden organizarse en forma coral o por contrastes, pero que, finalmente se constituyen en las bases de una narrativa épica sobre el pasado. Por otro, en los documentales que trabajan con una modalidad performativa, los testigos terminan subordinándose a la figura omnipresente del realizador que exhibe su manipulación de los testimonios, muchas veces fuerza las respuestas y enjuicia a los testigos en función de los objetivos del relato crítico con respecto al pasado que construyen.

Palabras y Cuentas del alma rompen esta disyuntiva de dos formas diferentes. El corto de Ana Mohaded lleva a un extremo la reflexión crítica sobre el acto de testimoniar, pero, a diferencia de la mayor parte de los documentales performativos, el testimonio puesto en cuestión es el de la propia realizadora. La película de Bomheker adopta una estética minimalista en relación con el testimonio. Solo presenta una testigo que plantea una lectura discordante del pasado y no la pone en cuestión, solo la escucha. De esta manera ambos trabajos rompen con los verosímiles sostenidos hasta el momento para validar las interpretaciones de la historia en los documentales de memoria. Excluyen la repetición interna de las figuras que testimonian y se abren a nuevos tópicos en base a los que se interpreta un pasado muchas veces evocado. Cada uno de los documentales que analizamos desarrolla la creación de un nuevo tipo de verosimilitud siguiendo su propia estrategia. En este punto resulta pertinente acudir a un clásico texto de Christian Metz (1968) en el que señala dos posibilidades de quiebre del verosímil, generación de un efecto de realidad y ampliación del campo de lo decible en el cine. Por una parte, siempre según Metz, se puede producir la ruptura exagerando y poniendo en evidencia las convenciones que sostienen el verosímil existente, tal como hace Ana Mohaded en Palabras. Por otra, se puede expandir el campo de lo decible introduciendo nuevas formas de 
Puras palabras. Sobre algunos de los usos de los testimonios en los documentales argentinos que evocan el pasado reciente

presentar personajes o situaciones cristalizados por verosímil, tal como hace Mario Bomheker en Cuentas del alma.

Las dos vías de innovación en la presentación de la forma de los contenidos, a su vez condicionan, dos maneras de construcción de la figura del autor y un planteo de relación con los posibles espectadores. Es decir, sostienen modalidades enunciativas diferentes. En este sentido vale la pena retomar las categorías desarrolladas por Christian Metz (1991) e Ismail Xavier (2008) que proponen dos tendencias en la forma de construcción de la enunciación cinematográfica: la que tiende a la opacidad y la que tiende a la transparencia. La primera, presente en la obra de Mohaded implica la existencia de marcas visibles en el texto del film que exponen su condición de constructo. La representación que realiza el documental se valida justamente porque el propio film da cuenta de la manipulación a la que somete al material con que trabaja. De esta manera, se abre la posibilidad, cumplida en Palabras, de construir una distancia crítica y reflexiva frente a las imágenes visuales y sonoras presentadas. La enunciación transparente, propia de la narrativa cinematográfica clásica, no exhibe (o exhibe lo menos posible) las marcas que dan cuenta del proceso de producción del film. Las imágenes parecen presentarse solas frente al espectador, tal como sucede en Cuentas del alma. Si bien esta distinción entre formas enunciativas se originó como modo de diferenciación de las estéticas cinematográficas clásica y moderna, dentro del cine contemporáneo se hibridan, coexisten y pueden o no fomentar una lectura distanciada de lo que se observa. Esta mirada crítica caracteriza a Palabras y Cuentas del alma. Planteando puntos de vista diferentes, ambos documentales cuestionan el modo en que se utilizan habitualmente los testimonios en los documentales de memoria argentinos.

Tal como plantea Javier Campo (2012) el documental (esto se hace cada vez visible en el contemporáneo) no puede encasillarse ni en una postura estética objetivista en la cual resulta indeseable la manipulación para presentar representaciones válidas del "mundo real" ni en una que niega la posibilidad de una correlación efectiva entre ese "mundo real" y las representaciones cinematográficas. Ni pura transparencia apenas mediada por la tecnología, ni pura convención, los documentales de Mohaded y Bomheker, abordan elementos que van más allá de la subjetividad de los realizadores y construyen una mirada que busca interpretar este "mundo real". En el caso de los films que analizamos el punto de partida que abre y organiza la lectura de un pasado que sin dudas existió, son las palabras de los testimonios. No solo resultan un vehículo fundamental para traer el pasado al presente y se convierten en el sostén 
de las narraciones sino que, además, a través la mis en scene de los testimonios delinean el punto de vista que interpreta los sucesos evocados.

Las rupturas de verosímil impulsadas por los documentales que analizamos dan cuenta de dos cuestiones que hasta el momento no habían sido demasiado abordadas por los documentales pero que en los estudios sobre los trabajos de memoria son consideradas importantes. Palabras hace visible el modo en que las diversas versiones de los recuerdos se van superponiendo y construyendo nuevas capas de memoria que se acumulan y modifican más allá de las voluntades personales. Cuentas del alma muestra la necesidad de una actitud de escucha para que las lecturas del pasado marginadas puedan ser transmitidas. Los dos documentales introducen novedades que actualizan las maneras en que se presentan las memorias sociales en los lenguajes audiovisuales. Sin embargo, quizás la principal de las contribuciones de ambos films sea que dejan claro que las interpretaciones del pasado que presentan no son las únicas posibles ni se presentan como definitivas. Esto no les resta importancia sino que aparecen como mojones significativos en el flujo y reflujo permanente de las memorias sociales que se sostienen nada más y nada menos que con recuerdos construidos con palabras.

\section{Referencias bibliográficas}

Aguilar, G. (2006). Otros mundos, un ensayo sobre el nuevo cine argentino. Buenos Aires: Santiago Arcos.

Aprea, G. (ed.). (2011). Filmar la memoria. Los documentales audiovisuales y la re-construcción del pasado. Los Polvorines: Universidad Nacional de General Sarmiento.

Aprea, G. (2015). Documental, testimonios y memorias. Miradas sobre el pasado militante. Buenos Aires: Manantial.

Calveiro, P. (1999). Poder y desaparición. Los campos de concentración en Argentina. Buenos Aires: Colihue.

Campo, J. (2012). Documental argentino. Entre el arte, la cultura y la política. Buenos Aires: Imago Mundi.

Cowie, E. (2011). Recording reality, desiring the real. Minneapolis - Londres: University off Minessota Press.

Feld, C. (2010). Imagen, memoria y desaparición. Una reflexión sobre los diversos soportes audiovisuales de la memoria. Aletheia, vol. 1. La Plata: Maestría en Historia y Memoria de la FaHCE de la UNLP. 
Puras palabras. Sobre algunos de los usos de los testimonios en los documentales argentinos que evocan el pasado reciente

Ferreyra, M. E. (2017). El pasado y sus lecturas. Representación de la memoria en el cine documental cordobés. Tesis para el Doctorado en Estudios Sociales de América Latina del Centro de Estudios Avanzados de la Universidad Nacional de Córdoba.

Lanza, P. (2016). Héroes y traidores: sobre los documentales de la militancia revolucionaria argentina. Imagofagia, (16). Buenos Aires: Asociación Argentina de Estudios de Cine y Audiovisual. Disponible en: www.asaeca.org/imagofagia/index.php/imagofagia/article/view/1137.

Longoni, A. (2007). Traiciones. La figura del traidor en los relatos acerca de los sobrevivientes de la represión. Buenos Aires: Grupo Norma.

Lvovich, D. \& Bisquert, J. (2008). La cambiante memoria de la dictadura. Buenos Aires: Biblioteca Nacional - Universidad Nacional de General Sarmiento.

Margulis, P. (2014). De la formación a la institución. El documental audiovisual en la transición democrática (1982-1990). Buenos Aires: Imago Mundi.

Metz, C. (1975 [1968]). El decir y lo dicho: ¿hacia la decadencia de un cierto verosímil?. In AA. VV. Lo verosímil. Buenos Aires: Tiempo Contemporáneo.

Metz, C. (1991). L'enonciation impersonnelle ou le site du film. Paris: Meridiens Klincksieck.

Moriconi, L. (2012). Voces filmadas: cine documental, testimonio y dictadura (Argentina, 1983-2002). Revista cine documental, (6). Buenos Aires. Disponible en: http://revista.cinedocumental.com.ar/6/teoria.html

Nichols, B. (2001). Introduction to documentary. Bloomington, IN: Indiana University Press.

Niney, F. (2009). Le documentaire et ses faux-semblants. Paris: Klincksieck.

Odin, R. (1984). Film documentaire, lecture documentarisante. In J. C. Lyant \& R. Odin (comps.), Cinéma et réalités. Travaux, (51): 263-267. Saint Etienne: Universidad de Saint-Étienne - CIEREC.

Pavis, P. (1998). Diccionario de teatro. Barcelona: Paidós.

Pessoa Ramos, F. (2011). A mis en scene do documentario. Revista cine documental, (4). Buenos Aires. Disponible en: http://revista.cinedocumental.c om.ar/4/teoria.html

Piedras, P. (2014). El documental en primera persona. Buenos Aires: Paidós.

Plantinga, C. (2010 [1997]). Rhetoric and representation in nonfiction film. Cambridge: Cambridge University Press. 
Renov, M. (1993). Toward a poetics of documentary. In M. Renov (ed.), Theorizing documentary (pp. 12-36). New York: American Film Institute/ Routledge.

Romano, S. \& Aguilar, G. (coords) (2101). ¿Qué he hecho yo para merecer esto?: guía para el investigador de medios audiovisuales en la Argentina. Buenos Aires: ASAECA.

Russo, E. (2009). Al filo de lo real. Líneas y bordes en el documental contemporáneo argentino. In J. Pena (ed.), Historias extraordinarias. Nuevo Cine argentino (1999-2008). Madrid: T\&B Editores.

Schefer, R. (2011). Vi-deo Memoria. Autobiografía, autorretrato, autoreferencialidad. In La fuga. Otoño de 2011. Santiago de Chile. Disponible en: www.lafuga.cl/videomemoria/451

Verzero, L. (2009). Estrategias para crear el mundo: la década del setenta en el cine documental de los dos mil. In C. Feld \& J. Stites Mor, El pasado que miramos. Memoria e imagen ante la historia reciente (pp. 181-217). Buenos Aires: Paidós.

Xavier, I. (2008). El discurso cinematográfico. La opacidad y la transparencia. Buenos Aires: Manantial.

\section{Filmografía}

Cazadores de utopías (1995), de David Blaustein.

Cuentas del alma. Confesiones de una guerrillera (2012), de Mario Bomheker.

Gaviotas blindadas (2006- 2008), de Mascaró Cine Americano.

Horas de vida (2006), Lucy Reyes.

Juan Germán y otras cuestiones (2005), de Jorge Dente.

La escuela (2006), de Eduardo Yedra.

La noche del golpe de estado. Lisboa, 1974 (2001), de Ginette Lavigne.

La secretaria de Hitler (2001), de André Heller y Othmar Schmiderer.

Los rubios (2003), de Albertina Carri.

$M$ (2007), de Nicolás Prividera.

Montoneros, una historia (1994), de Andrés Di Tella.

Palabras (2009), de Ana Mohaded.

Trelew (2003), de Mariana Arruti.

Última carta sobre la revolución (2016), de Pablo Spatola. 